Atmos. Chem. Phys., 13, 10159-10170, 2013

www.atmos-chem-phys.net/13/10159/2013/

doi:10.5194/acp-13-10159-2013

(c) Author(s) 2013. CC Attribution 3.0 License.

\title{
Long-term measurements of particle number size distributions and the relationships with air mass history and source apportionment in the summer of Beijing
}

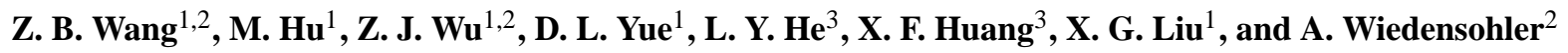 \\ ${ }^{1}$ State Key Joint Laboratory of Environmental Simulation and Pollution Control, College of Environmental Sciences and \\ Engineering, Peking University, Beijing 100871, China \\ ${ }^{2}$ Leibniz Institute for Tropospheric Research, Permoserstr. 15, 04318 Leipzig, Germany \\ ${ }^{3}$ Key Laboratory for Urban Habitat Environmental Science and Technology, School of Environment and Energy, \\ Peking University Shenzhen Graduate School, Shenzhen 518055, China
}

Correspondence to: M. Hu (minhu@pku.edu.cn)

Received: 31 December 2012 - Published in Atmos. Chem. Phys. Discuss.: 22 February 2013

Revised: 11 August 2013 - Accepted: 9 September 2013 - Published: 16 October 2013

\begin{abstract}
A series of long-term and temporary measurements were conducted to study the improvement of air quality in Beijing during the Olympic Games period (8-24 August 2008). To evaluate actions taken to improve the air quality, comparisons of particle number and volume size distributions of August 2008 and 2004-2007 were performed. The total particle number and volume concentrations were $14000 \mathrm{~cm}^{-3}$ and $37 \mu \mathrm{m}^{-3} \mathrm{~cm}^{-3}$ in August of 2008 , respectively. These were reductions of $41 \%$ and $35 \%$ compared with mean values of August 2004-2007. A cluster analysis on air mass history and source apportionment were performed, exploring reasons for the reduction of particle concentrations. Back trajectories were classified into five major clusters. Air masses from the south direction are always associated with pollution events during the summertime in Beijing. In August 2008, the frequency of air mass arriving from the south was 1.3 times higher compared to the average of the previous years, which however did not result in elevated particle volume concentrations in Beijing. Therefore, the reduced particle number and volume concentrations during the 2008 Beijing Olympic Games cannot be only explained by meteorological conditions. Four factors were found influencing particle concentrations using a positive matrix factorization (PMF) model. They were identified as local and remote traffic emissions, combustion sources as well as secondary transformation. The reductions of the four sources were calculated to $47 \%, 44 \%, 43 \%$ and $30 \%$, re-
\end{abstract}

spectively. The significant reductions of particle number and volume concentrations may attribute to actions taken, focusing on primary emissions, especially related to the traffic and combustion sources.

\section{Introduction}

The effects of aerosol particles on ecology, climate, and health-related issues are the central topics in current environmental research. Particle mass concentration attracts more attention due to its negative impact on the air quality and urban visibility (Molina and Molina, 2004). Recent evidences indicated that the number concentration of ultrafine particles should get equal or even more attention than the particle mass concentration in terms of health effects (Oberdorster et al., 2005). Moreover, not only the particle number concentration is important but also the particle number size distribution (Kumar et al., 2010). However, air quality standards (such as $\mathrm{PM}_{2.5}$ and $\mathrm{PM}_{10}$ ) are developed to control the particle mass concentration. The mass of ultrafine particles $\left(D_{\mathrm{p}}<100 \mathrm{~nm}\right)$, which dominates the particle number concentration, is negligible. The current air quality standards may thus be insufficient to draw a whole picture on the aerosol impacts, especially to ecology and health effects. Measurements of particle number distributions are one piece

Published by Copernicus Publications on behalf of the European Geosciences Union. 
of the entire mosaic to understand better all kind of impacts of atmospheric aerosol particles.

Measurements of particle number size distributions have been conducted in diverse environments since the 1990s (Kulmala et al., 2004; Holmes, 2007). However, long-term measurements were mainly performed in Europe and North America (Asmi et al., 2011; Kulmala et al., 2004). Although a few intensive campaigns had been conducted in the heavily polluted environments such as Mexico (Dunn et al., 2004), New Delhi (Mönkkönen et al., 2005), and the Pearl River delta region (Liu et al., 2008; Yue et al., 2010a; Wang et al., 2013b), long-term measurements of particle number size distributions in developing countries have only been carried out in urban Beijing since 2004 (Wehner et al., 2004) and in the North China Plain since 2008 (Shen et al., 2011). Previous results showed that Aitken mode particles account for about half of the total particle number concentrations, indicating the strong influences of traffic emissions in urban areas (Wu et al., 2008). Meanwhile, particle number concentrations especially in the accumulation mode range were 4 times higher than those in the cities of developed countries, suggesting more serious air pollution in urban Beijing (Wu et al., 2008; Wehner et al., 2008).

With the rapid urbanization and motorization, Beijing is one of the biggest megacities in the world with a population of more than 15 million people and over 3.5 million vehicles in 2008 (http://www.stats.gov.cn/). The air quality problem is characterized by high concentrations of fine particles and ozone in Beijing (Shao et al., 2006; Streets et al., 2007). As the host city of 29th Olympic Games, "Green Olympics" was proposed as one of the three themes. A series of control measures had been conducted by the government gradually. The air quality in August 2008 had been the best for any summer period over the last few years (UNEP, 2009). This achievement has been attributed to painstaking efforts in industrial restructuring and application of environmental protection technologies since 1998 as well as temporary measures taken during Olympic Game periods, especially revolved around vehicles (Zhou et al., 2010; Hao et al., 2006). Many estimation results focusing on the air quality during the 2008 Olympic Games period have been reported (M. Wang et al., 2009; W. T. Wang et al., 2009; X. Wang et al., 2009, Y. Wang et al., 2009, Wang et al., 2010; Zhou et al., 2010; Wang and Xie, 2009). On average, $\mathrm{PM}_{2.5}$ and $\mathrm{PM}_{10}$ concentrations were $31 \%$ and $35 \%$ lower, respectively, during the Olympic period compared to the nonOlympic period (W. T. Wang et al., 2009). The model results showed that the average reductions of $\mathrm{PM}_{10}, \mathrm{CO}$, and $\mathrm{NO}_{2}$ were $28 \%, 19.3 \%$, and $12.3 \%$, respectively, in the case of a $32.3 \%$ reduction of the traffic flow (Wang and Xie, 2009). A mobile laboratory study revealed that the on-road air pollutant concentrations decreased by $54 \%$ for CO, $41 \%$ for $\mathrm{NO}_{\mathrm{x}}$ and $12 \%$ for black carbon during the Olympics compared to the pre-control time period (M. Wang et al., 2009). In addition, previous research also suggested that besides the emission controls, meteorological conditions such as wind direction and precipitation were also important in producing low aerosol concentrations appearing (Gao et al., 2011).

However, these studies only concern the variations of pollutants (such as pollutant gases and particle mass concentration) before and during the Olympic Games. The control measures focused on the traffic emission were the most important ones taken in August 2008. Previous studies reported that the contributions of vehicle source to particle mass concentration $\left(\mathrm{PM}_{10}\right)$ varied in a wind range, accounting for more than $30 \%$ in the megacities and less than $5 \%$ at some rural sites (Viana et al., 2008). At an urban site in Beijing, the contribution of traffic source to $\mathrm{PM}_{2.5}$ was only $6 \%$ (Song et al., 2006). However, the source related to traffic emissions had a significant contribution to total particle number concentration, which accounted for about $40 \%$ in northern Sweden (Krecl et al., 2008) and Pittsburgh (Zhou et al., 2004), and even up to $78 \%$ in Erfurt (Yue et al., 2008). Hence, in this study, we aim to evaluate the traffic control measures during the Olympic Games in view of particle number concentration, which has not been done before.

This investigation was based on the long-term measurements of particle number size distributions during five consecutive Augusts from 2004 to 2008. Relationships between particle number size distributions and air mass origin or source apportionment were explored in order to answer the following questions: (1) how can one evaluate the air quality during the 2008 Olympic Games based on the particle number size distributions and (2) which actions were most responsible for the reductions of particle number and volume concentrations?

\section{Experimental}

\subsection{Sampling site}

The sampling site was located on the sixth floor of an academic building (about $20 \mathrm{~m}$ above the ground level) on the campus of the Peking University (PKU; $39.99^{\circ} \mathrm{N}$, $116.31^{\circ} \mathrm{E}$ ), in the northwestern urban area of Beijing, outside the 4th Ring Road. The PKU site is assumed as representative of a typical urban site of Beijing. For detailed descriptions of the measurement site we refer the reader to $\mathrm{Wu}$ et al. (2007).

\subsection{Instrumentation}

Number size distributions of atmospheric particles have been measured by a TDMPS (twin differential mobility particle sizer) system with $10 \mathrm{~min}$ time resolution at PKU site since March 2004. The measured size range is 3-800 nm (mobility diameter) from 2004 to 2006 and 3-900 nm in 2007-2008. The system is composed of two parallel Hauke-type differential mobility analyzers (DMAs) that classify particles in the size ranges 3-80 nm and larger than $40 \mathrm{~nm}$, counting using condensation particle counter (CPC, TSI Inc., St. Paul, 
MN, USA) models 3025 and 3010, respectively. The relative humidity within the systems was kept below $40 \%$ by adding a silica-gel dryer in the inlet line and in the sheath air cycle to avoid condensation of water in the inlet systems during humid days, especially in summertime. The particle number size distributions were corrected for particle losses inside of the TDMPS and in the sampling, following the method of "equivalent length" as described in Wiedensohler et al. (2012). Particle volume concentrations were calculated from the measured number size distributions, assuming spherical particles. Considering that the 2008 summer Olympic Games were held from 8 to 24 August in 2008, we chose only data of measurements taken in August from 2004 to 2008 in this investigation.

To evaluate the air quality during the Olympic Games, an intensive campaign called CAREBeijing 2008 was performed from beginning of July to the end of September. The $\mathrm{PM}_{1}$ particle mass concentration and chemical components (sulfate, nitrate, ammonium, chloride and organic matter) measurements were carried out using an Aerodyne highresolution time-of-flight aerosol mass spectrometer (HRToFAMS) (Huang et al., 2010). The detection limits of sulfate, nitrate, ammonium, chloride, and organics were calculated to be $0.008,0.004,0.026,0.004$, and $0.033 \mu \mathrm{g} \mathrm{m}^{-3}$, respectively. Meanwhile, four organic components including a hydrocarbon-like (HOA), a cooking-related (COA), and two oxygenated (OOA-1 and OOA-2) organic aerosols were identified. All the data were averaged to $10 \mathrm{~min}$ in order to keep consistent with the particle number size distribution. A detailed instrumentation description of HR-ToFAMS can be found in Huang et al. (2010). BC concentrations were measured using a multi-angle absorption photometer (MAAP, Thermo Model 5012).

Meteorological conditions including air temperature $(T)$, relative humidity (RH), wind speed (WS) and precipitation were measured at a meteorological station at $200 \mathrm{~m}$ distance from the sampling site.

\subsection{Methods}

\subsubsection{Back trajectory analysis}

To investigate the influence of the air mass history and to obtain a better understanding of regional atmospheric aerosol properties, the back trajectory analysis was performed using the HYbrid Single Particle Lagrangian Integrated Trajectory (HYSPLIT4) model developed by NOAA/ARL to follow the history of air masses arriving at measurement site (Draxler and Rolph, 2012; Rolph, 2012). The meteorological input data used in the model were obtained from the NOAA ARL archives (http://ready.arl.noaa.gov/archives.php). In this investigation, $48 \mathrm{~h}$ back trajectories were chosen, and four trajectories per day (00:00, 06:00, 12:00, and 18:00) were calculated. The trajectories terminated at a height of $500 \mathrm{~m}$ above ground level. In addition, a hierarchical clustering algorithm was applied to group in total 620 backward trajectories (five years of August measurements) into different transport patterns according to their similarity in spatial distribution using the HYSPLIT4 software.

\subsubsection{Source apportionment}

Positive matrix factorization (PMF) is a powerful multivariate factor analysis tool to decompose the observed data into two matrices: factor contributions and factor profiles (Paatero and Tapper, 1994). In this study, the source apportionment is achieved using the EPA PMF 3.0 version (EPA, 2008). The basic source-receptor model in matrix form can be simply presented as

$\mathbf{X}_{i j}=\sum_{k=1}^{p} G_{i k} F_{k j}+E_{i j}$

Here a data matrix $\mathbf{X}_{i j}$ is observed particle number size distributions composed of $i$ by $j$ dimensions, in which $i$ number of samples and $j$ the size bins were measured. $G_{i k}$ is the number concentration of particles from the $k$-th source associated with the $i$-th sample, and $F_{k j}$ is the size distribution profile associated with $k$-th source. $E_{i j}$ is the residual for each sample.

To evaluate the reductions of diverse sources, we assumed that the source profile was consistent in August from 2004 to 2008. It appears that some of the sampling days had nucleation and subsequent growth occurring. The mean frequency of new particle formation event was $10 \%$ in August from 2004 to 2008. The basic assumption of the receptor model is that the ambient data are the sum of constant particle number size distribution profiles from the contributing sources (Zhou et al., 2004). Considering that nucleation is a strong source of newly formed particles, the days with intense nucleation events in the data set were thus excluded for this study. These days were classified as the criteria described in Wu et al. (2007), with the particle number concentrations exceeding $10^{4} \mathrm{~cm}^{-3}$ in the $3-10 \mathrm{~nm}$ range for $2.5 \mathrm{~h}$. Overall, the whole data set includes 16170 individual particle number size distributions with 30 size intervals.

Measurement uncertainty is one input parameter for the PMF analysis. In this study, an equation-based method was taken to calculate the measurement uncertainty. Two parameters including the method detection limit (MDL) and error fraction are involved in the equation-based method (EPA, 2008). The detection limit of the TDMPS was calculated by particle number concentration divided by raw counts of CPC for each size bins. The mean result is shown in Fig. 1. Error sources for the measurements of particle number size distribution include the aerosol flow rate, the DMA, CPC counting efficiency and the correction for diffusion losses as described above. Considering these error sources, the error fraction was estimated as 15 (the percent uncertainty multiplied by 100) for particles smaller than $25 \mathrm{~nm}$ and 10 for particles larger 
Table 1. Detailed information of different traffic control stages.

\begin{tabular}{lll}
\hline Title & Time Periods & Major control measures \\
\hline Before control (BC) & Pre-1 July & Control 50\% of governmental cars since 23 June \\
\hline $\begin{array}{l}\text { Traffic Control-I } \\
\text { (TC-I) }\end{array}$ & 1-19 July & Control total 300 000 heavy-polluting vehicles \\
\hline $\begin{array}{l}\text { Traffic Control-II } \\
\text { (TC-II) }\end{array}$ & $\begin{array}{l}\text { Before Olympics } \\
\text { (20 July-7 August); between } \\
\text { Olympics and Paralympics } \\
\text { (24 August-6 September) }\end{array}$ & $\begin{array}{l}\text { The even- and odd-numbered license plate rule was } \\
\text { enforced (control 45 \% of total vehicles) } \\
\text { Stricter control on vehicles entering in Beijing }\end{array}$ \\
\hline $\begin{array}{l}\text { Traffic Control-III } \\
\text { (TC-III) }\end{array}$ & $\begin{array}{l}\text { During the Olympics } \\
\text { (8-23 August) } \\
\text { and Paralympics } \\
\text { (7-19 September) }\end{array}$ & $\begin{array}{l}\text { Control extra 20\% of governmental cars } \\
\text { Stop outdoor construction activities }\end{array}$ \\
& After 20 September & $\begin{array}{l}\text { Increase bus number and frequency } \\
\text { Post-control }\end{array}$ \\
$\begin{array}{l}\text { PC) } \\
\text { instead by limitation system for the ending number } \\
\text { (control 20 \% of private cars) }\end{array}$ \\
\hline
\end{tabular}

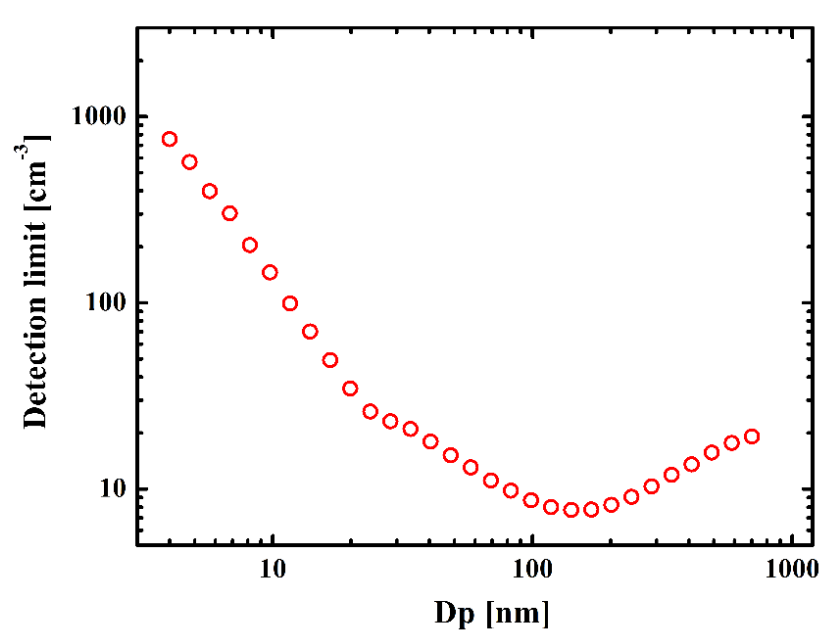

Fig. 1. TDMPS detection limit versus particle diameter.

than $25 \mathrm{~nm}$. If the number concentration is less than or equal to the MDL provided, the uncertainty (Unc) is calculated by the following equation:

$\mathrm{Unc}=\frac{5}{6} \times \mathrm{MDL}$.

If the particle number concentration is greater than the MDL provided, the uncertainty is calculated:

$\mathrm{Unc}=\sqrt{(\text { error fraction } \times \text { concentration })^{2}+\mathrm{MDL}^{2}}$.

Different numbers of factors and $F_{\text {peak }}$ values have been explored to obtain the most meaningful results. $F_{\text {peak }}$ is a parameter to control the rotation in PMF model by changing (adding or subtracting) the rows and columns of $F$ and $G$ matrices from each other depending on the sign of the $F_{\text {peak }}$ value (Paatero et al., 2002). The PMF was run several times

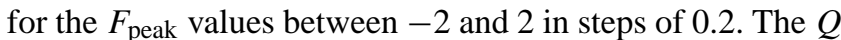
value is an assessment of how well the model fits the input data and is calculated using the following equation:

$Q=\sum_{i=1}^{n} \sum_{j=1}^{m}\left[\frac{\mathbf{X}_{i j}-\sum_{k=1}^{p} G_{i k} F_{k j}}{U_{i j}}\right]$

with $U$ as the uncertainty. The $Q$ value versus $F_{\text {peak }}$ plot shows a typical "U" shape with the lowest $Q$ value corresponding to $F_{\text {peak }}$ of 0 , which is selected in this study. The theoretical $Q\left(Q_{\exp }\right)$ is estimated by using the following equation: $n m-p(n+m)$, where $n$ is the bins number of the profile of the particle number size distribution, $m$ the number of samples in the data set, and $p$ the number of factors fitted by the model. If the assumption that the source profile and the estimation of the errors in the input data are accurate, solutions with numbers of factors that give $Q / Q_{\exp }$ near 1 should be obtained (Ulbrich et al., 2009). The value of $Q / Q_{\exp }$ is 0.96 when the factor number is chosen as 4 in this study.

\section{Results and discussion}

\subsection{General overview}

Several temporary measures were taken to improve the air quality in August 2008 (see Table 1). Starting 1 July, a total of 30000 diesel and heavy-polluting vehicles were not allowed to drive in Beijing. Meanwhile, only those vehicles meeting emission standards equivalent to Euro 2 were allowed to enter Beijing. From 20 July, the even- and oddnumbered license plate rule was enforced, which might 
Table 2. Statistics of meteorological parameters in August from 2004 to 2008.

\begin{tabular}{ccccc}
\hline Year & $\begin{array}{c}T \\
\left({ }^{\circ}\right)\end{array}$ & $\begin{array}{c}\mathrm{RH} \\
(\%)\end{array}$ & $\begin{array}{c}\text { WS } \\
\left(\mathrm{m} \mathrm{s}^{-1}\right)\end{array}$ & $\begin{array}{c}\text { Total precipitation }(\mathrm{mm}) / \\
\text { number of rainy days }\end{array}$ \\
\hline 2004 & $25.5 \pm 3.6$ & $60 \pm 21$ & $1.3 \pm 0.8$ & $56 / 6$ \\
2005 & $27.9 \pm 3.6$ & $68 \pm 17$ & $1.2 \pm 0.8$ & $92 / 6$ \\
2006 & $27.6 \pm 3.7$ & $71 \pm 18$ & $1.2 \pm 1.0$ & $98 / 5$ \\
2007 & $28.2 \pm 4.4$ & $59 \pm 18$ & $1.0 \pm 1.2$ & $116 / 5$ \\
2008 & $27.5 \pm 4.0$ & $69 \pm 17$ & $0.9 \pm 0.9$ & $150 / 5$ \\
\hline
\end{tabular}

have controlled $45 \%$ of total vehicles. Moreover, an extra $20 \%$ of governmental cars were not allowed to drive during the Olympics and Paralympics (8-23 August and 7-19 September). Meanwhile, outdoor construction activities were stopped, and some gas stations were closed.

Figure 2 illustrates the mean particle number size distributions during the different control stages corresponding to Table 1. It is obvious that since the diesel and heavy-duty vehicles were prohibited from driving in Beijing, the particle number concentrations, especially in the size range of 70 $110 \mathrm{~nm}$, showed a significant decrease, implying the traffic control measures were effective. Total particle number and volume concentrations were $13700 \mathrm{~cm}^{-3}$ and $40 \mu \mathrm{m}^{-3} \mathrm{~cm}^{-3}$ during the Olympics and Paralympics (TC-III stage), respectively, which were $16 \%$ and $41 \%$ lower than those $\left(16300 \mathrm{~cm}^{-3}\right.$ and $68 \mu^{-3} \mathrm{~cm}^{-3}$ ) before control periods. It is surprising that we found, during the most strict measures taken in the period TC-III, that the number concentration of ultrafine particles was even higher than that in the TCII stage. This phenomenon might have been due to the local emissions at the campus. The table tennis competition gymnasium for the 2008 Beijing Olympics was located about $200 \mathrm{~m}$ away from the sampling site at Peking University. The traffic was busy on the days with table tennis matches during the TC-III stage around the gymnasium, which might have produced more ultrafine particles.

The influence of the local meteorology on the air quality cannot be ignored. The meteorological condition can be characterized by high temperatures, high humidity, and low wind speed in Beijing in August, while the relatively stable weather conditions and less rainfall, which favor the accumulation of particulate matter, were observed in autumn $(\mathrm{Wu}$ et al., 2008). Hence, to avoid the impact of varied meteorological conditions in different seasons, we have to only rely on the data set in August.

The statistics of various meteorological parameters in August from 2004 to 2008 are listed in Table 2. The highest mean temperature $\left(28.2^{\circ} \mathrm{C}\right)$ and relative humidity $(71 \%)$ were observed in 2007 and 2006, respectively. The average wind speeds (WS) were around $1 \mathrm{~m} \mathrm{~s}^{-1}$, and the dominate wind was from north and northwest in five summers. The lowest total precipitation amount was $56 \mathrm{~mm}$ in 2004 and highest with $150 \mathrm{~mm}$ in 2008 . However, the precipitation fre-

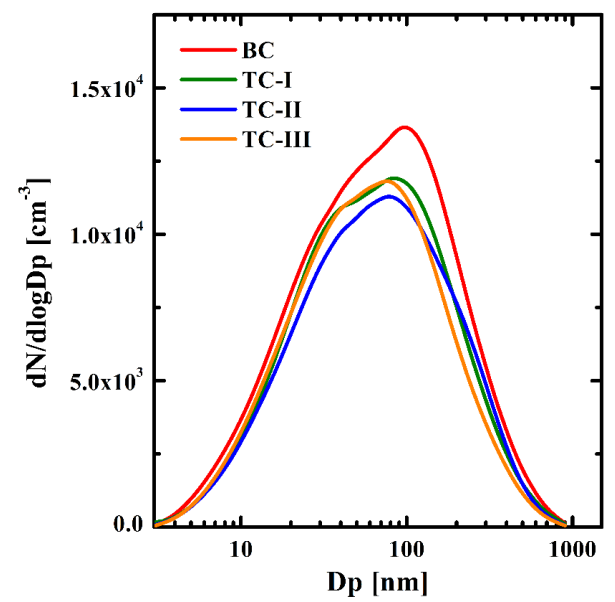

Fig. 2. Mean particle number size distributions in different control stages corresponding to Table 1.
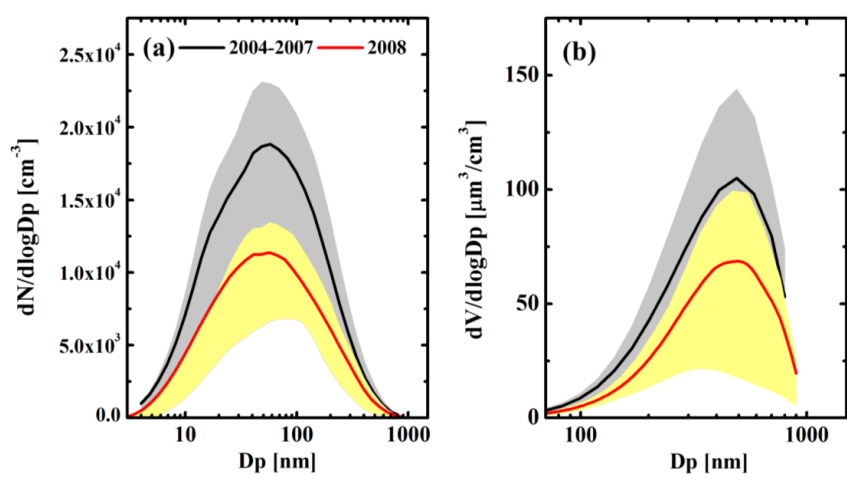

Fig. 3. Mean particle (a) number and (b) volume size distributions in August from 2004 to 2007 (black line) and 2008 (red line). The upper and lower boundaries of shaded areas indicate the 75th and 25 th percentiles.

quency was almost the same in August of these five years, indicating heavier rainfall events in August 2008. Precipitation is an important way to remove atmospheric aerosol particles. Previous studies (Gao et al., 2011; J. P. Zhang et al., 2012) indicated the important roles of atmospheric circulation and precipitation on the air quality during the 2008 Beijing Olympic Games. Hence, to avoid the influence of the precipitation, the particle number size distributions during rainfall events were also excluded from the data set for further analysis.

Figure 3 displays the variations of number and volume size distributions of aerosol particles as a mean for August periods 2004-2007 and 2008. The shapes of mean particle number and volume size distributions were shown as the unimodal distribution, with the peaks around $50 \mathrm{~nm}$ and $450 \mathrm{~nm}$, respectively. The total particle number concentrations were dominated by the ultrafine particles, which account for more than $70 \%$. The lowest total particle number and volume concentrations were observed in August 2008, 

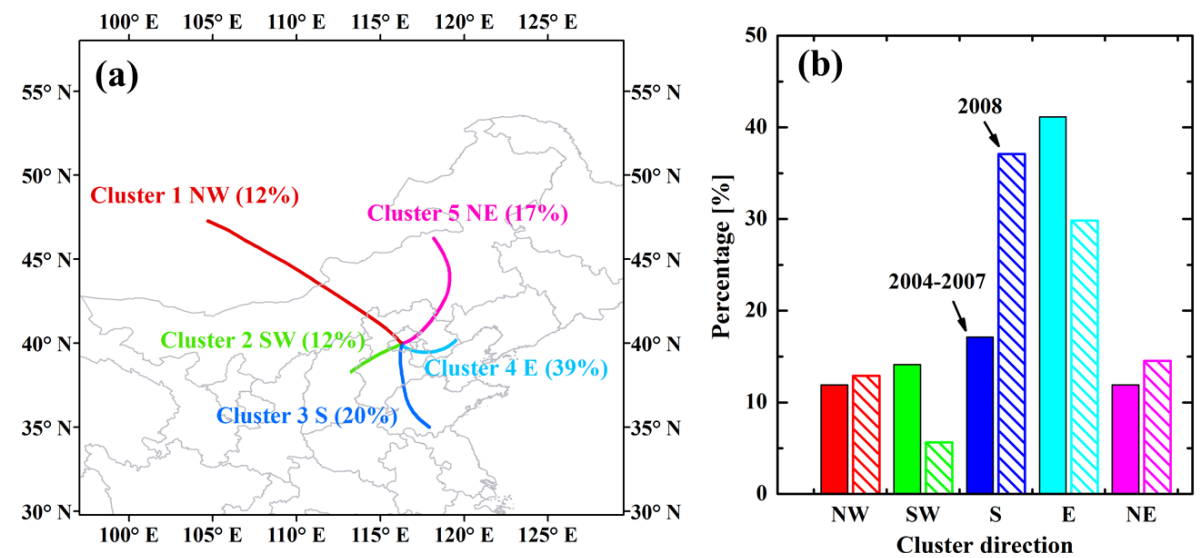

Fig. 4. Mean back trajectories for five trajectory clusters arriving at the PKU site in August 2004-2008 (left panel) and the mean frequencies of five trajectory clusters from 2004 to 2007 and 2008 (right panel). The directions of five trajectory clusters are northwest (NW, red), southwest (SW, green), south (S, blue), east (E, cyan) and northeast (NE, pink), respectively.

with mean values of $14000 \mathrm{~cm}^{-3}$ and $37 \mu \mathrm{m}^{-3} \mathrm{~cm}^{-3}$, respectively. To obtain a more logical view on the reduction values of 2008, the comparisons between the average value of 20042007 (Ave. 2004-2007) and 2008 (Ave. 2008) were investigated in this study. Mode-related particle number and volume concentrations are listed in Table 3. Here, we defined the nucleation, Aitken and accumulation modes to the particle size ranges of $3-20 \mathrm{~nm}, 20-100 \mathrm{~nm}$ and $100-800 \mathrm{~nm}$, respectively, following the two-year statistical analysis in a previous study (Wu et al., 2008). Significant decreases of number concentrations in diverse modes were found. During the August 2008 period, the average number concentrations of nucleation, Aitken and accumulation mode particles were $2800 \mathrm{~cm}^{-3}, 7400 \mathrm{~cm}^{-3}$ and $3800 \mathrm{~cm}^{-3}$, respectively, corresponding to $5200 \mathrm{~cm}^{-3}, 12600 \mathrm{~cm}^{-3}$ and $6400 \mathrm{~cm}^{-3}$ during Augusts in 2004-2007.

The nucleation mode particles are essential to the total aerosol number concentrations, especially during new particle formation (NPF) event days in urban Beijing (Zhang, 2010; R. Zhang et al., 2012; Yue et al., 2010b; Wang et al., 2013a). The numbers of NPF event days were 8 and 6 during 2004-2007 and 2008, respectively. However, the higher NPF event frequency in August 2008 did not result in the higher number concentration for nucleation mode particles, which was reduced by $46 \%$ compared with the August periods 2004-2007. This phenomenon could be ascribed to two reasons: firstly, the various actions taken during the Olympic periods reduced the emissions of gaseous precursors of newly formed particles such as $\mathrm{SO}_{2}$ and volatile organic compounds (VOCs) (M. Wang et al., 2009). Hence, even though we observed more NPF events, the strength of nucleation event was decreased, suggesting fewer small particles were observed in 2008. Secondly, we considered the PKU site as representative of the urban environment of Beijing. The nucleation mode particles are not only produced during the atmospheric nucleation process, but also by the fresh traffic emissions.
Therefore, like the Aitken mode particles, traffic emissions are also a major source of nucleation mode particles at the PKU site (Wu et al., 2007). Several temporal measures, as we discussed before, had been taken during the summertime in 2008, resulting in significant reductions both in nucleation and Aitken modes particles. In addition, to reduce the local combustion sources, companies (e.g., Beijing Steel Corporation) were forced to move to neighboring provinces prior to the Olympic Games period (UNEP, 2009). As a result, the mean volume concentration in August 2008 was only $64 \%$ compared to the average of the August 2004 to 2007 periods.

\subsection{Back trajectory cluster analysis}

The ground-based measurements in the summer of 2006 proved that the air pollution in Beijing is mainly a regional problem (Guo et al., 2010; Takegawa et al., 2009). The air quality of Beijing was determined by the source emissions from both the megacity and the surrounding provinces depending on the meteorological air mass history. Hence, to explore the impacts of the air mass history on the reduction of particle number and volume concentrations in 2008, the HYSPLIT4 model was used to follow the history of air masses arriving in Beijing.

The five-cluster analysis is the optimum solution according to the change in total spatial variance, with the mean back trajectory of each cluster presented in Fig. 4a. Each of the clusters represents between 75 and 250 back trajectories. The mean back trajectories show significant differences in direction and length. Three short-length trajectory clusters 2, 3 and 4 arrived from the southern and eastern sections, while the other two from the north direction. The air masses from the east (39\%) and the south $(20 \%)$ direction are the dominate trajectories for August periods. Figure 5 exhibits the median particle number size distributions for five trajectory clusters from 2004 to 2007 and 2008. The particle 


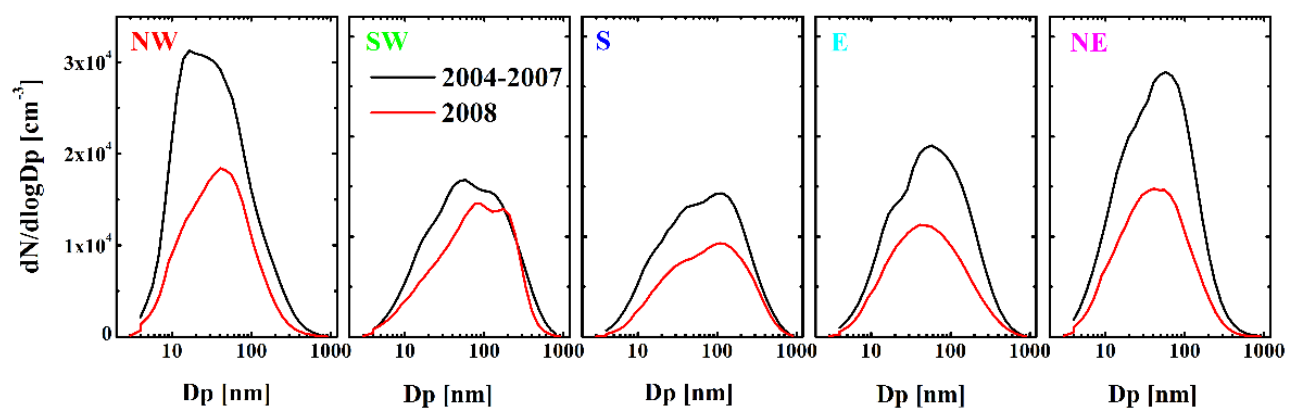

Fig. 5. Mean particle number size distributions for five trajectory clusters, according to the classification in Fig. 3. Black line indicates the mean values from 2004 to 2007, and the red line represents the mean values of 2008 .

Table 3. Comparisons of particle number and volume concentrations between different modes (mean \pm standard deviation).

\begin{tabular}{lccccc}
\hline & \multicolumn{2}{c}{ Number concentration $\left(\mathrm{cm}^{-3}\right)$} & \multicolumn{2}{c}{ Volume concentration $\left(\mu \mathrm{m}^{-3} \mathrm{~cm}^{-3}\right)$} \\
& Nucleation & Aitken & Accumulation & Total & Total \\
\hline Size range $(\mathrm{nm})$ & $3-20$ & $20-100$ & $100-800$ & $3-800$ & $3-800$ \\
Ave. 2004-2007 & $5000 \pm 5500$ & $12300 \pm 6200$ & $6400 \pm 2800$ & $23900 \pm 10000$ & $57 \pm 36$ \\
Ave. 2008 & $2800 \pm 4200$ & $7400 \pm 4400$ & $3800 \pm 2000$ & $14000 \pm 7000$ & $37 \pm 30$ \\
\hline
\end{tabular}

number size distributions of different air mass types mostly peak around 40-200 nm, whereas the maxima of particle volume size distributions are at around 400-600 $\mathrm{nm}$. The mean total particle number concentrations from north directions (NW and NE) were $31200 \mathrm{~cm}^{-3}$ and $21700 \mathrm{~cm}^{-3}$, respectively, which are higher than the air masses that came from other directions (Table 4). On the contrary, more volume concentrations were observed for the air masses from the southwest and the south, with mean values of $80 \mu^{-3} \mathrm{~cm}^{-3}$ and $67 \mu \mathrm{m}^{-3} \mathrm{~cm}^{-3}$, respectively, which are 2 times higher than those from other directions. These results are consistent with a previous study that the slow southern wind controlled by high pressure systems always indicates the polluted situation for the case of Beijing (Wehner et al., 2008; Shen et al., 2011). The huge discrepancy of particle volume concentrations in five trajectories suggested that the air mass history has a significant impact on air quality. However, the frequency of air masses from the polluted southern direction (southwest and south) was $43 \%$ in 2008, which is 1.3 times higher than that $(31 \%)$ in 2004-2007 (Fig. 4b). Although the air mass condition in 2008 was not favorable to reduce particle concentration, still the lowest particle volume concentration had been observed (Fig. 3b). This phenomenon indicated that the good air quality during the 2008 Olympic Games could not be only ascribed to the air mass conditions.

Furthermore, no matter from which direction the air mass arrived, the lowest particle number and volume concentrations were observed in 2008. This implied that the reduction of the pollutants could be attributed to the abatement measures taken in Beijing and neighboring provinces during this period. The reductions of total particle number and volume concentrations calculated as the difference between the 2008 value and the mean of 2004-2007 are listed in Table 4 . The reductions of particle number and volume concentrations varied from 24 to $46 \%$ and 23 to $56 \%$ for the five clusters, respectively. The highest reductions of total particle number concentrations ( $46 \%$ ) were observed in both the cluster 1 and the cluster 5 . The reduction of total particle volume concentrations was more than $40 \%$ in all clusters except cluster 3 . This might be caused by the high frequency of trajectory cluster 3 in 2008 .

\subsection{Source apportionment}

The results have pointed out so far that the improved air quality in August 2008 might not have been only ascribed to the influence of different meteorological conditions such as air mass history. The reduction of source emissions is also a major factor that could be ignored. Therefore, we tried to identify the sources based on particle number size distribution profiles using a PMF model and get detailed information on the variations of source emissions.

The mean modeled profiles of particle number size distribution for each factor are presented in Figure 6a. The four factors are arranged in order of increasing peak diameter from factor 1 to factor 4 . The modeled particle number size distribution (dashed line) is the sum of four factors. The correlation coefficient $R^{2}$ between observed and modeled particle number concentration in each size interval varied in a wide range, only about 0.5 in small diameter $(<10 \mathrm{~nm})$ and up to 0.95 in larger size $(>15 \mathrm{~nm})$. The weak correlation in small particles might be due to the high uncertainty during the measurement. In total, the mean modeled total 
Table 4. Statistics of the particle number and volume concentrations for five trajectory clusters. The reduction is calculated by the equation: Ave. (2004-2007) - Ave. (2008)/Ave. (2004-2007).

\begin{tabular}{|c|c|c|c|c|c|c|c|c|}
\hline & \multicolumn{4}{|c|}{ Total number concentration $\left(\mathrm{cm}^{-3}\right)$} & \multicolumn{4}{|c|}{ Total volume concentration $\left(\mu \mathrm{m}^{3} \mathrm{~cm}^{-3}\right)$} \\
\hline & 2004-2008 & 2004-2007 & 2008 & reduction & 2004-2008 & 2004-2007 & 2008 & reduction \\
\hline Cluster 1 & 31200 & 36000 & 19500 & $46 \%$ & 36 & 37 & 16 & $56 \%$ \\
\hline Cluster 2 & 18000 & 21000 & 16000 & $24 \%$ & 80 & 85 & 51 & $40 \%$ \\
\hline Cluster 3 & 15800 & 19100 & 11900 & $38 \%$ & 67 & 78 & 60 & $23 \%$ \\
\hline Cluster 4 & 21700 & 23000 & 13400 & $42 \%$ & 55 & 60 & 33 & $45 \%$ \\
\hline Cluster 5 & 27100 & 30200 & 16500 & $46 \%$ & 32 & 32 & 14 & $55 \%$ \\
\hline
\end{tabular}
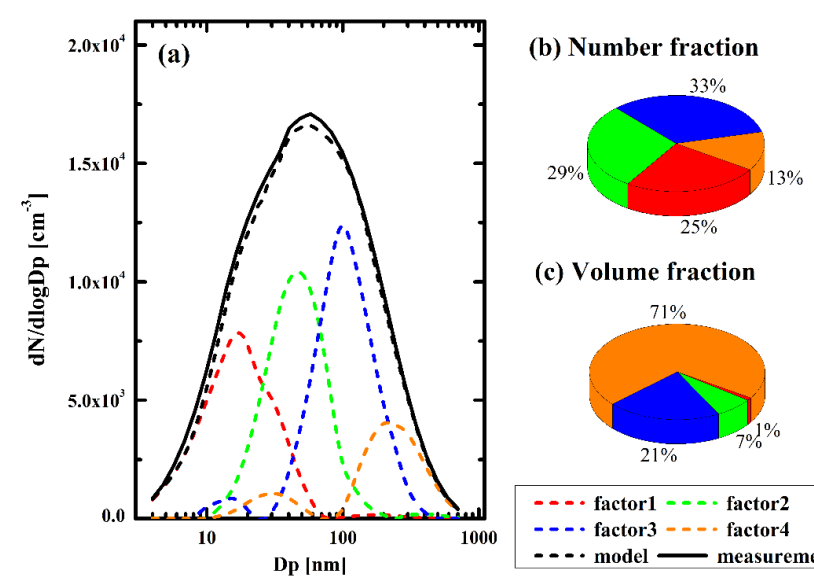

(c) Volume fraction

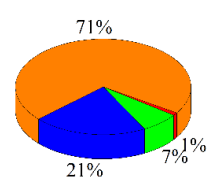

- - factor 1 - - . factor 2

- - f factor 3 - - - factor 4

-... model $\longrightarrow$ measurement

Fig. 6. (a) Number size distribution profiles of four factors. The black dashed and solid lines present the modeled and observed particle number size distributions, respectively; (b) and (c) are the fractions of four factors in particle number and volume concentrations.

particle number concentration could explain $96 \%$ of the observation data, varying from 82 to $99 \%$ at $7 \mathrm{~nm}$ and $120 \mathrm{~nm}$, respectively. Source contributions of factors combined with gaseous and particle chemical component information could help us to identify the sources of four factors. However, we only have the complete data set during the CAREBeijing2008 intensive campaign. Hence, we choose here the data set in 2008 as an example to identify the major source of each factor.

The number size distribution of factor 1 has a peak diameter of $16 \mathrm{~nm}$, as shown in Fig. 6a. Although this factor has only little contribution to the volume concentration (1\%), it represents however $25 \%$ of the number concentration (see Fig. $6 b$ and c). The shape of this factor profile is similar to the shape of particle number size distributions measured at a roadside (Wehner et al., 2002; Virtanen et al., 2006; Gramotnev and Ristovski, 2004), indicating its relation to car traffic. The strong diurnal variation shows obvious peaking during morning and evening rush hours, which is similar to the diurnal variation of $\mathrm{NO}_{\mathrm{x}}$, suggesting that factor 1 is likely to be particle nucleation induced by traffic emissions (Fig. 7). The pattern of this factor in Beijing is similar to the local traffic

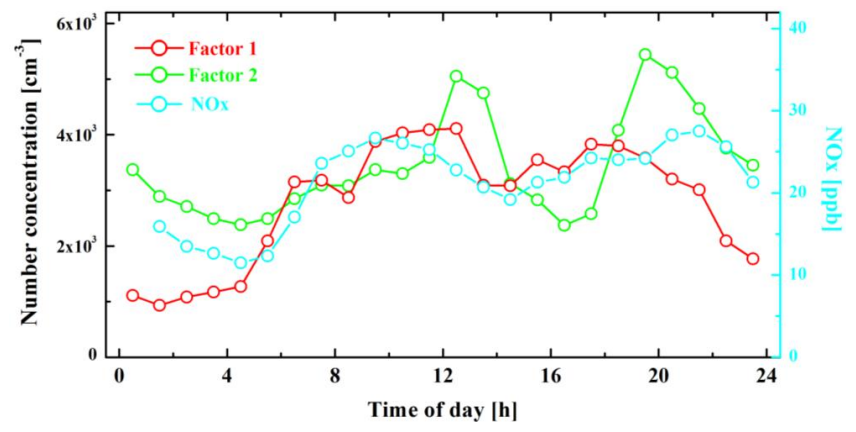

Fig. 7. Diurnal variations of $\mathrm{NO}_{\mathrm{x}}$ (cyan) and particle number concentration of factor 1 (red) and factor 2 (green).

factor found in previous studies (Zhou et al., 2004, 2005; Yue et al., 2008).

The particle number size distribution of factor 2 is dominated by the ultrafine particles in the size range between 10 and $100 \mathrm{~nm}$ with the peak diameter around $50 \mathrm{~nm}$. It provides $29 \%$ of the particle number concentration but only $7 \%$ to the volume concentration. The diurnal variation shows the peaks have a delay after rush hour (Fig. 7). This should also apply to traffic-related particles, but it is not the same as factor 1, possibly aged particles from more distant areas of the sampling site. In addition, evidence from other research had shown that diesel and gasoline engine vehicles emit particles in this range (Harris and Maricq, 2001; Kittelson et al., 2006). Factor 2 seems consistent with other findings (Zhou et al., 2005; Kim et al., 2004; Yue et al., 2008), and can be interpreted and named as remote traffic. Nevertheless, the differences between these two factors only behaved on geometric mean diameter.

The peak of the number size distribution of factor 3 is at $100 \mathrm{~nm}$. This factor accounts for $33 \%$ of the total number concentration and $21 \%$ of the total volume concentration. Similar diurnal variation trends are observed between number concentration of factor 3 and black carbon concentration (see Fig. 8a). Recent studies in China have shown that the number size distribution of particles emitted by the combustion sources such as power station or biomass burning also shows the peak in the diameter around $100 \mathrm{~nm}$ (Yi et al., 


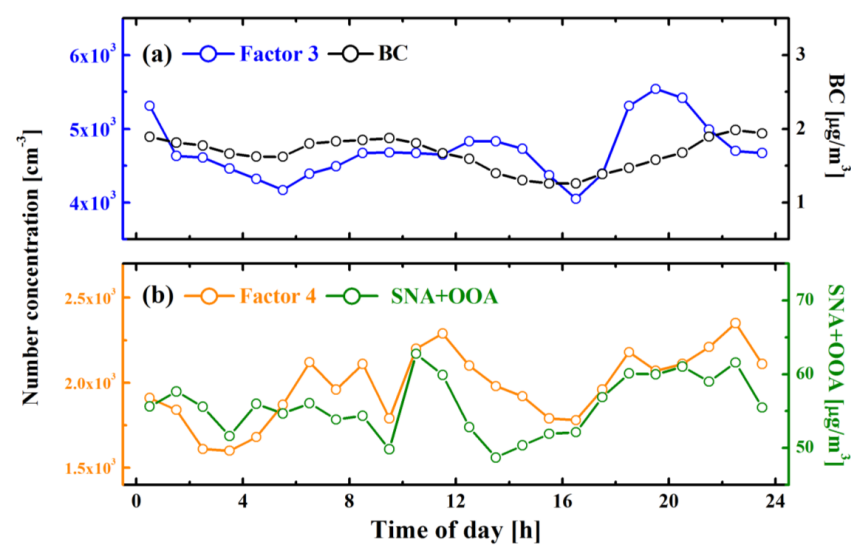

Fig. 8. Diurnal variations of (a) particle number concentration of factor 3 (blue) and BC concentration (black); and (b) particle number concentration of factor 4 (orange) and the sum of sulfate, nitrate, ammonium and oxygenated organic aerosol organic concentration (green).

2006; Li et al., 2007). Hence, factor 3 is mainly contributed by other combustion source besides car traffic.

A bimodal particle number size distribution with the peaks $30 \mathrm{~nm}$ and $200 \mathrm{~nm}$ characterizes factor 4 . The concentration of this factor does not change obviously with time, which coincides with a previous study (Kim et al., 2004). Figure 8b depicts the high correlation between the daily pattern of factor 4 and secondary aerosol such as SNA (sulfate, nitrate and ammonium) and OOA (oxygenated organic aerosol organic). The sources of factor 4 seem to be rather complex, origination from the accumulation of secondary aerosol mass growing on pre-existing particles. This factor contributes to number $(13 \%)$ and significantly to the volume (71\%) concentration.

Overall, we could assume that factors 1-3 are related to the primary emission, and factor 4 represents the secondary aerosol mass. The box plot in Fig. 9 shows the statistics of the source contributions of each factor. The lower source contributions in all four factors of August 2008 were observed compared with the results between 2004 and 2007. The reductions of source contributions for the four factors were $47 \%, 44 \%, 43 \%$ and $30 \%$, respectively. The obvious reductions of factors related to traffic and combustion showed that the measures taken focused on the primary emissions during the Olympic Games periods are significant. Factor 4, which is assumed as secondary aerosol formation, does not show the corresponding rate of decline trend with the reduced primary emissions, indicating long-range transport of aerosol precursors to be less affected by the reduction measures.

\section{Conclusions}

As the host city of the 29th Olympic Games, the municipal government of Beijing has been working on improv-

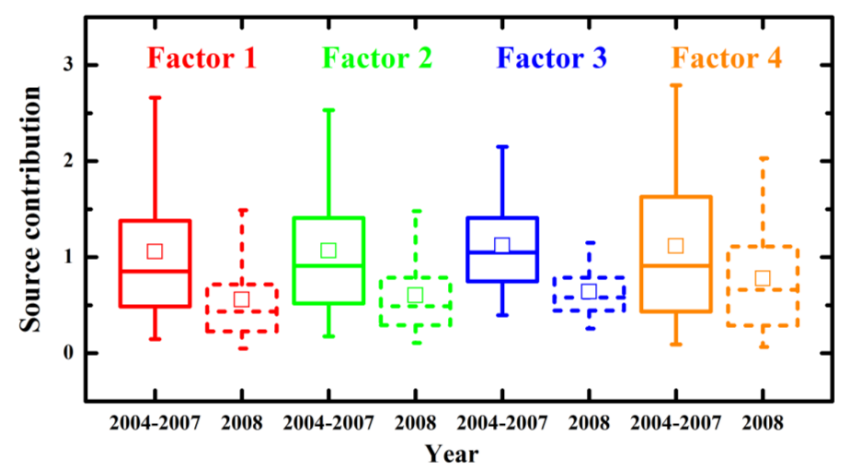

Fig. 9. Box plots of the source contributions from 2004 to 2007 (solid) and 2008 (dashed) for 4 factors. Source contribution values are normalized. The upper and lower boundaries of boxes indicate the 75th and 25th percentiles; the line within the box marks the median; the whiskers above and below boxes indicate the 95th and 5 th percentiles; and square symbols represent the means.

ing the air quality for the last decade. This study successfully demonstrated that the air quality was improved significantly during the Olympic Games period, which was evaluated based on the long-term measurements of particle number size distributions since 2004 .

The mean total particle number and volume concentrations (in the size range $3-800 \mathrm{~nm}$ ) were $14000 \mathrm{~cm}^{-3}$ and $37 \mu^{-3} \mathrm{~cm}^{-3}$ in August 2008, respectively. The lowest particle number concentrations in three modes of nucleation $(3-20 \mathrm{~nm})$, Aitken $(20-100 \mathrm{~nm})$ and accumulation (100$800 \mathrm{~nm}$ ) were observed in August of 2008 among five years, with reductions of $46 \%, 42 \%$ and $40 \%$, respectively, compared with the mean values of August 2004 to 2007 periods.

Back trajectory cluster analysis was performed to investigate the impacts of the air mass history on the reduction of particle concentrations. In total five significant trajectory clusters have been identified. The results showed that the air masses from the east (39\%) and south $(20 \%)$ directions dominated for August periods. The air masses from the south (southwest and south) always indicated the polluted situation with increased particle mass concentrations for the case of Beijing. For the Olympic Games period August 2008, a higher frequency $(43 \%)$ of these air masses was observed compared to the August periods 2004 to 2007 (31\%). In addition, the lowest particle number and volume concentrations were observed no matter from which direction the air masses came from originally. The reductions of total particle number and volume concentrations varied from 24 to $46 \%$ and 23 to $56 \%$, respectively, for all trajectory clusters, with mean values of 41 and $35 \%$. This evidence implies that the reductions of particle number and volume concentrations could not only be ascribed to the air mass origins during the Olympic periods.

In this investigation, we also applied the PMF model to explore the source apportionment of particle number size 
distributions. Four factors have been identified based on their unique size patterns and the correlations with other chemical components. We can assume that factors 1-3 are related to the primary emission, in which factors 1 and 2 are related to the traffic emission and factor 3 to other combustion sources. These three factors account for $87 \%$ of total particle number concentration. Factor 4 could be assigned to secondary aerosol formation, which has a great contribution to volume concentration $(71 \%)$. The reductions of source contribution for the four factors were $47 \%, 44 \%, 43 \%$ and $30 \%$, respectively. These results indicated that the significant reductions of particle concentrations might be attributed to the measures taken focused on the primary emissions, especially related to the traffic and combustion sources.

Overall, this study illustrated that the control strategies implemented by urban Beijing were able to affect short-term improvements in air quality. However, the evidence revealed that emissions from regional sources could also affect the air quality. Thus, even though the traffic control policy has favorable effects in the urban area and achieves air quality improvement, pollution controls in the surrounding regions are needed and should be taken into consideration in the future.

Acknowledgements. This work is supported by the National Natural Science Foundation of China (21025728 and 21190052), the Chinesisch-Deutsches Zentrum für Wissenschaftsförderung (GZ663) and the China Ministry of Environmental Protection's Special Funds for Scientific Research on Public Welfare (201009002). The authors would like to thank Xiaoyang Liu and Jietai Mao (Department of Atmospheric and Oceanic Sciences, Peking University) for providing meteorological data.

Edited by: X. Liu

\section{References}

Asmi, A., Wiedensohler, A., Laj, P., Fjaeraa, A.-M., Sellegri, K., Birmili, W., Weingartner, E., Baltensperger, U., Zdimal, V., Zikova, N., Putaud, J.-P., Marinoni, A., Tunved, P., Hansson, H.C., Fiebig, M., Kivekäs, N., Lihavainen, H., Asmi, E., Ulevicius, V., Aalto, P. P., Swietlicki, E., Kristensson, A., Mihalopoulos, N., Kalivitis, N., Kalapov, I., Kiss, G., de Leeuw, G., Henzing, B., Harrison, R. M., Beddows, D., O’Dowd, C., Jennings, S. G., Flentje, H., Weinhold, K., Meinhardt, F., Ries, L., and Kulmala, M.: Number size distributions and seasonality of submicron particles in Europe 2008-2009, Atmos. Chem. Phys., 11, 5505-5538, doi:10.5194/acp-11-5505-2011, 2011.

Draxler, R. R. and Rolph, G. D.: HYSPLIT (HYbrid Single-Particle Lagrangian Integrated Trajectory) Model access via NOAA ARL READY Website (http://ready.arl.noaa.gov/HYSPLIT. php), NOAA Air Resources Laboratory, Silver Spring, MD, 2012.

Dunn, M. J., Jimenez, J. L., Baumgardner, D., Castro, T., McMurry, P. H., and Smith, J. N.: Measurements of Mexico City nanoparticle size distributions: Observations of new par- ticle formation and growth, Geophys. Res. Lett., 31, L10102, doi:10.1029/2004g1019483, 2004.

EPA: Positive Matrix Factorization (PMF) 3.0 Fundamentals \& User Guide, Washington, DC, 2008.

Gao, Y., Liu, X., Zhao, C., and Zhang, M.: Emission controls versus meteorological conditions in determining aerosol concentrations in Beijing during the 2008 Olympic Games, Atmos. Chem. Phys., 11, 12437-12451, doi:10.5194/acp-11-12437-2011, 2011.

Gramotnev, G. and Ristovski, Z.: Experimental investigation of ultra-fine particle size distribution near a busy road, Atmos. Environ., 38, 1767-1776, doi:10.1016/j.atmosenv.2003.12.028, 2004.

Guo, S., Hu, M., Wang, Z. B., Slanina, J., and Zhao, Y. L.: Sizeresolved aerosol water-soluble ionic compositions in the summer of Beijing: implication of regional secondary formation, Atmos. Chem. Phys., 10, 947-959, doi:10.5194/acp-10-947-2010, 2010.

Hao, J. M., Hu, J. N., and Fu, L. X.: Controlling vehicular emissions in Beijing during the last decade, Transport Res. A-Pol., 40, 639651, doi:10.1016/j.tra.2005.11.005, 2006.

Harris, S. J. and Maricq, M. M.: Signature size distributions for diesel and gasoline engine exhaust particulate matter, J. Aerosol Sci., 32, 749-764, 2001.

Holmes, N. S.: A review of particle formation events and growth in the atmosphere in the various environments and discussion of mechanistic implications, Atmos. Environ., 41, 2183-2201, doi:10.1016/j.atmosenv.2006.10.058, 2007.

Huang, X.-F., He, L.-Y., Hu, M., Canagaratna, M. R., Sun, Y., Zhang, Q., Zhu, T., Xue, L., Zeng, L.-W., Liu, X.-G., Zhang, Y.-H., Jayne, J. T., Ng, N. L., and Worsnop, D. R.: Highly time-resolved chemical characterization of atmospheric submicron particles during 2008 Beijing Olympic Games using an Aerodyne High-Resolution Aerosol Mass Spectrometer, Atmos. Chem. Phys., 10, 8933-8945, doi:10.5194/acp-10-8933-2010, 2010.

Kim, E., Hopke, P. K., Larson, T. V., and Covert, D. S.: Analysis of ambient particle size distributions using unmix and positive matrix factorization, Environ. Sci. Technol., 38, 202-209, doi:10.1021/Es030310s, 2004.

Kittelson, D. B., Watts, W. F., and Johnson, J. P.: On-road and laboratory evaluation of combustion aerosols - Part 1: Summary of diesel engine results, J. Aerosol Sci., 37, 913-930, doi:10.1016/j.jaerosci.2005.08.005, 2006.

Krecl, P., Hedberg Larsson, E., Ström, J., and Johansson, C.: Contribution of residential wood combustion and other sources to hourly winter aerosol in Northern Sweden determined by positive matrix factorization, Atmos. Chem. Phys., 8, 3639-3653, doi:10.5194/acp-8-3639-2008, 2008.

Kulmala, M., Vehkamäki, H., Petäjä, T., Dal Maso, M., Lauri, A., Kerminen, V. M., Birmili, W., and McMurry, P. H.: Formation and growth rates of ultrafine atmospheric particles: a review of observations, J. Aerosol Sci., 35, 143-176, doi:10.1016/j.jaerosci.2003.10.003, 2004.

Kumar, P., Robins, A., Vardoulakis, S., and Britter, R.: A review of the characteristics of nanoparticles in the urban atmosphere and the prospects for developing regulatory controls, Atmos. Environ., 44, 5035-5052, doi:10.1016/j.atmosenv.2010.08.016, 2010.

Li, X., Duan, L., Wang, S., Duan, J., Guo, X., Yi, H., Hu, J., Li, C., and Hao, J.: Emission Characteristics of Particulate Matter from Rural Household Biofuel Combustion in China, Energ. Fuel., 21, 845-851, doi:10.1021/ef060150g, 2007. 
Liu, S., Hu, M., Wu, Z. J., Wehner, B., Wiedensohler, A., and Cheng, Y. F.: Aerosol number size distribution and new particle formation at a rural/coastal site in Pearl River Delta (PRD) of China, Atmos. Environ., 42, 6275-6283, doi:10.1016/j.atmosenv.2008.01.063, 2008.

Molina, M. J. and Molina, L. T.: Megacities and atmospheric pollution, J. Air Waste Manage., 54, 644-680, 2004.

Mönkkönen, P., Koponen, I. K., Lehtinen, K. E. J., Hämeri, K., Uma, R., and Kulmala, M.: Measurements in a highly polluted Asian mega city: observations of aerosol number size distribution, modal parameters and nucleation events, Atmos. Chem. Phys., 5, 57-66, doi:10.5194/acp-5-57-2005, 2005.

Oberdorster, G., Oberdorster, E., and Oberdorster, J.: Nanotoxicology: An emerging discipline evolving from studies of ultrafine particles, Environ. Health Persp., 113, 823-839, doi:10.1289/Ehp.7339, 2005.

Paatero, P. and Tapper, U.: Positive Matrix Factorization - a Nonnegative Factor Model with Optimal Utilization of ErrorEstimates of Data Values, Environmetrics, 5, 111-126, 1994.

Paatero, P., Hopke, P. K., Song, X.-H., and Ramadan, Z.: Understanding and controlling rotations in factor analytic models, Chemom. Intell. Lab. Syst., 60, 253-264, doi:10.1016/s01697439(01)00200-3, 2002.

Rolph, G. D.: Real-time Environmental Applications and Display sYstem (READY) Website (http://ready.arl.noaa.gov), NOAA Air Resources Laboratory, Silver Spring, MD, 2012.

Shao, M., Tang, X. Y., Zhang, Y. H., and Li, W. J.: City clusters in China: air and surface water pollution, Front. Ecol. Environ., 4, 353-361, 2006.

Shen, X. J., Sun, J. Y., Zhang, Y. M., Wehner, B., Nowak, A., Tuch, T., Zhang, X. C., Wang, T. T., Zhou, H. G., Zhang, X. L., Dong, F., Birmili, W., and Wiedensohler, A.: First long-term study of particle number size distributions and new particle formation events of regional aerosol in the North China Plain, Atmos. Chem. Phys., 11, 1565-1580, doi:10.5194/acp-11-15652011, 2011.

Song, Y., Zhang, Y. H., Xie, S. D., Zeng, L. M., Zheng, M., Salmon, L. G., Shao, M., and Slanina, S.: Source apportionment of $\mathrm{PM}_{2.5}$ in Beijing by positive matrix factorization, Atmos. Environ., 40, 7661-7662, doi:10.1016/j.atmosenv.2006.09.006, 2006.

Streets, D. G., Fu, J. H. S., Jang, C. J., Hao, J. M., He, K. B., Tang, X. Y., Zhang, Y. H., Wang, Z. F., Li, Z. P., Zhang, Q., Wang, L. T., Wang, B. Y., and Yu, C.: Air quality during the 2008 Beijing Olympic Games, Atmos. Environ., 41, 480-492, doi:10.1016/j.atmosenv.2006.08.046, 2007.

Takegawa, N., Miyakawa, T., Kuwata, M., Kondo, Y., Zhao, Y., Han, S., Kita, K., Miyazaki, Y., Deng, Z., Xiao, R., Hu, M., van Pinxteren, D., Herrmann, H., Hofzumahaus, A., Holland, F., Wahner, A., Blake, D. R., Sugimoto, N., and Zhu, T.: Variability of submicron aerosol observed at a rural site in Beijing in the summer of 2006, J. Geophys. Res.-Atmos., 114, D00g05, doi:10.1029/2008jd010857, 2009.

Ulbrich, I. M., Canagaratna, M. R., Zhang, Q., Worsnop, D. R., and Jimenez, J. L.: Interpretation of organic components from Positive Matrix Factorization of aerosol mass spectrometric data, Atmos. Chem. Phys., 9, 2891-2918, doi:10.5194/acp-9-2891-2009, 2009.

UNEP: Independent Environmental Assessment Beijing 2008 Olympic Games, 2009.
Viana, M., Kuhlbusch, T. A. J., Querol, X., Alastuey, A., Harrison, R. M., Hopke, P. K., Winiwarter, W., Vallius, A., Szidat, S., Prevot, A. S. H., Hueglin, C., Bloemen, H., Wahlin, P., Vecchi, R., Miranda, A. I., Kasper-Giebl, A., Maenhaut, W., and Hitzenberger, R.: Source apportionment of particulate matter in Europe: A review of methods and results, J. Aerosol Sci., 39, 827-849, doi:10.1016/j.jaerosci.2008.05.007, 2008.

Virtanen, A., Rönkkö, T., Kannosto, J., Ristimäki, J., Mäkelä, J. M., Keskinen, J., Pakkanen, T., Hillamo, R., Pirjola, L., and Hämeri, K.: Winter and summer time size distributions and densities of traffic-related aerosol particles at a busy highway in Helsinki, Atmos. Chem. Phys., 6, 2411-2421, doi:10.5194/acp-6-2411-2006, 2006.

Wang, M., Zhu, T., Zheng, J., Zhang, R. Y., Zhang, S. Q., Xie, X. X., Han, Y. Q., and Li, Y.: Use of a mobile laboratory to evaluate changes in on-road air pollutants during the Beijing 2008 Summer Olympics, Atmos. Chem. Phys., 9, 8247-8263, doi:10.5194/acp-9-8247-2009, 2009.

Wang, S. X., Zhao, M., Xing, J., Wu, Y., Zhou, Y., Lei, Y., He, K. B., Fu, L. X., and Hao, J. M.: Quantifying the Air Pollutants Emission Reduction during the 2008 Olympic Games in Beijing, Environ. Sci. Technol., 44, 2490-2496, doi:10.1021/es9028167, 2010.

Wang, T. and Xie, S. D.: Assessment of traffic-related air pollution in the urban streets before and during the 2008 Beijing Olympic Games traffic control period, Atmos. Environ., 43, 5682-5690, doi:10.1016/j.atmosenv.2009.07.034, 2009.

Wang, W. T., Primbs, T., Tao, S., and Simonich, S. L. M.: Atmospheric Particulate Matter Pollution during the 2008 Beijing Olympics, Environ. Sci. Technol., 43, 5314-5320, 2009.

Wang, X., Westerdahl, D., Chen, L. C., Wu, Y., Hao, J. M., Pan, X. C., Guo, X. B., and Zhang, K. M.: Evaluating the air quality impacts of the 2008 Beijing Olympic Games: On-road emission factors and black carbon profiles, Atmos. Environ., 43, 45354543, doi:10.1016/j.atmosenv.2009.06.054, 2009.

Wang, Y., Hao, J., McElroy, M. B., Munger, J. W., Ma, H., Chen, D., and Nielsen, C. P.: Ozone air quality during the 2008 Beijing Olympics: effectiveness of emission restrictions, Atmos. Chem. Phys., 9, 5237-5251, doi:10.5194/acp-9-5237-2009, 2009.

Wang, Z. B., Hu, M., Sun, J. Y., Wu, Z. J., Yue, D. L., Shen, X. J., Zhang, Y. M., Pei, X. Y., and Wiedensohler, A.: Characteristics of regional new particle formation in urban and regional background environments in the North China Plain, Atmos. Chem. Phys. Discuss., 13, 20531-20560, doi:10.5194/acpd-13-205312013, 2013a.

Wang, Z. B., Hu, M., Yue, D. L., He, L. Y., Huang, X. F., Yang, Q., Zheng, J., Zhang, R. Y., and Zhang, Y. H.: New particle formation in the presence of a strong biomass burning episode at a downwind rural site in PRD, China, Tellus B, 65, 19965, doi:10.3402/tellusb.v65i0.19965, 2013b.

Wehner, B., Birmili, W., Gnauk, T., and Wiedensohler, A.: Particle number size distributions in a street canyon and their transformation into the urban-air background: measurements and a simple model study, Atmos. Environ., 36, 2215-2223, doi:10.1016/S1352-2310(02)00174-7, 2002.

Wehner, B., Wiedensohler, A., Tuch, T. M., Wu, Z. J., Hu, M., Slanina, J., and Kiang, C. S.: Variability of the aerosol number size distribution in Beijing, China: New particle formation, dust 
storms, and high continental background, Geophys. Res. Lett., 31, L22108, doi:10.1029/2004g1021596, 2004.

Wehner, B., Birmili, W., Ditas, F., Wu, Z., Hu, M., Liu, X., Mao, J., Sugimoto, N., and Wiedensohler, A.: Relationships between submicrometer particulate air pollution and air mass history in Beijing, China, 2004-2006, Atmos. Chem. Phys., 8, 6155-6168, doi:10.5194/acp-8-6155-2008, 2008.

Wiedensohler, A., Birmili, W., Nowak, A., Sonntag, A., Weinhold, K., Merkel, M., Wehner, B., Tuch, T., Pfeifer, S., Fiebig, M., Fjäraa, A. M., Asmi, E., Sellegri, K., Depuy, R., Venzac, H., Villani, P., Laj, P., Aalto, P., Ogren, J. A., Swietlicki, E., Williams, P., Roldin, P., Quincey, P., Hüglin, C., Fierz-Schmidhauser, R., Gysel, M., Weingartner, E., Riccobono, F., Santos, S., Grüning, C., Faloon, K., Beddows, D., Harrison, R., Monahan, C., Jennings, S. G., O’Dowd, C. D., Marinoni, A., Horn, H.-G., Keck, L., Jiang, J., Scheckman, J., McMurry, P. H., Deng, Z., Zhao, C. S., Moerman, M., Henzing, B., de Leeuw, G., Löschau, G., and Bastian, S.: Mobility particle size spectrometers: harmonization of technical standards and data structure to facilitate high quality long-term observations of atmospheric particle number size distributions, Atmos. Meas. Tech., 5, 657-685, doi:10.5194/amt5-657-2012, 2012.

Wu, Z. J., Hu, M., Liu, S., Wehner, B., Bauer, S., Ma ßling, A., Wiedensohler, A., Petäjä, T., Dal Maso, M., and Kulmala, M.: New particle formation in Beijing, China: Statistical analysis of a 1-year data set, J. Geophys. Res., 112, D09209, doi:10.1029/2006jd007406, 2007.

Wu, Z. J., Hu, M., Lin, P., Liu, S., Wehner, B., and Wiedensohler, A.: Particle number size distribution in the urban atmosphere of Beijing, China, Atmos. Environ., 42, 7967-7980, doi:10.1016/j.atmosenv.2008.06.022, 2008.

Yi, H. H., Hao, J. M., Duan, L., Li, X. H., and Guo, X. M.: Characteristics of inhalable particulate matter concentration and size distribution from power plants in China, J. Air Waste Manage., 56, 1243-1251, 2006.

Yue, D. L., Hu, M., Wu, Z. J., Guo, S., Wen, M. T., Nowak, A., Wehner, B., Wiedensohler, A., Takegawa, N., Kondo, Y., Wang, X. S., Li, Y. P., Zeng, L. M., and Zhang, Y. H.: Variation of particle number size distributions and chemical compositions at the urban and downwind regional sites in the Pearl River Delta during summertime pollution episodes, Atmos. Chem. Phys., 10, 9431-9439, doi:10.5194/acp-10-9431-2010, 2010a.
Yue, D. L., Hu, M., Zhang, R. Y., Wang, Z. B., Zheng, J., Wu, Z. J., Wiedensohler, A., He, L. Y., Huang, X. F., and Zhu, T.: The roles of sulfuric acid in new particle formation and growth in the mega-city of Beijing, Atmos. Chem. Phys., 10, 4953-4960, doi:10.5194/acp-10-4953-2010, 2010b.

Yue, W., Stolzel, M., Cyrys, J., Pitz, M., Heinrich, J., Kreyling, W. G., Wichmann, H. E., Peters, A., Wang, S., and Hopke, P. K.: Source apportionment of ambient fine particle size distribution using positive matrix factorization in Erfurt, Germany, Sci. Total Environ., 398, 133-144, doi:10.1016/j.scitotenv.2008.02.049, 2008.

Zhang, J. P., Zhu, T., Zhang, Q. H., Li, C. C., Shu, H. L., Ying, Y., Dai, Z. P., Wang, X., Liu, X. Y., Liang, A. M., Shen, H. X., and Yi, B. Q.: The impact of circulation patterns on regional transport pathways and air quality over Beijing and its surroundings, Atmos. Chem. Phys., 12, 5031-5053, doi:10.5194/acp-12-50312012, 2012.

Zhang, R., Khalizov, A., Wang, L., Hu, M., and Xu, W.: Nucleation and Growth of Nanoparticles in the Atmosphere, Chem. Rev., 112, 1957-2011, doi:10.1021/cr2001756, 2012.

Zhang, R. Y.: Getting to the Critical Nucleus of Aerosol Formation, Science, 328, 1366-1367, doi:10.1126/science.1189732, 2010.

Zhou, L. M., Kim, E., Hopke, P. K., Stanier, C. O., and Pandis, S.: Advanced factor analysis on Pittsburgh particle size-distribution data, Aerosol Sci. Technol., 38, 118-132, 2004.

Zhou, L. M., Kim, E., Hopke, P. K., Stanier, C., and Pandis, S. N.: Mining airborne particulate size distribution data by positive matrix factorization, Chem. Rev., 110, D07s19, doi:10.1029/2004jd004707, 2005.

Zhou, Y., Wu, Y., Yang, L., Fu, L., He, K., Wang, S., Hao, J., Chen, J., and Li, C.: The impact of transportation control measures on emission reductions during the 2008 Olympic Games in Beijing, China, Atmos. Environ., 44, 285-293, 2010. 